\title{
Kejadian Stunting di Tinjau dari Pola Makan dan Tinggi Badan Orang Tua Anak Usia 12-36 Bulan di Puskesmas Kinoivaro Kabupaten Sigi Provinsi Sulawesi Tengah
}

\author{
Miftakhur Rohmah ${ }^{1 *}$, Regina Safira Natalie ${ }^{2}$ \\ ${ }^{1}$ Institut Ilmu Kesehatan STRADA Indonesia \\ ${ }^{2}$ Akademi Kebidanan Graha Ananda Palu, Indonesia \\ Corresponding author: Miftakhur Rohmah (m1111ftaa@gmail.com) \\ Received: Mei, 20 2020; Accepted: June, 28 2020; Published: September, 12020
}

\begin{abstract}
ABSTRAK
Masih tingginya angka kejadian stunting di wilayah Puskesmas Kinovaro sehingga dapat meningkatkan morbiditas dan mortalitas di suatu daerah tersebut, hal ini disebabkan salah satunya oleh pola pemebrian makan dan tinggi badan orang tua. Tujuan penelitian ini adalah untuk menganalisis kejadian stunting yang di tinjau dari pola makan dan tinggi badan orang tua anak usia 12-36 bulan di puskesmas Kinovaro Sulawesi Tengah. Jenis penelitian ini adalah studi analitik observasional dengan pendekatan Cross-sectional. Populasi dan sampel pada penelitian ini yaitu orang tua dan anak stunting usia 12-36 bulan dengan jumlah sampel sebanyak 85 responden, menggunakan tehnik simple random sampling, dengan penggumpulan data menggunakan kuesioner dan observasi. Analisis data yang digunakan adalah Uji Phi dengan nilai signifikasi $\alpha=0,05$. Pada hasil penelitain ini didapatkan Sebagian besar 47 anak (56\%) responden dengan kejadian stunting sangat pendek, kategori pendek 38 responden (44\%). Pada Pola makan didapatkan Sebagian besar 63 responden $(74 \%)$ pada kategori tidak tepat. Pada tinggi badan ayah didapatkan Sebagian besar 58 responden $(68 \%)$ pada kategori $\geq 161,9 \mathrm{~cm}$, tinggi badan ibu didapatkan sebagian besar 55 responden $(64 \%)$ pada kategori $\geq 150 \mathrm{~cm}$ dari 85 responden. Pada Uji statistik Phi menunjukkan bahwa tidak terdapat hubungan antara Pola pemberian makan $p$-value $>\alpha 0,05(0,562>0,05)$ dan Tinggi Badan Ibu $p$-value $>$ $\alpha 0,05(0,119>0,05)$ dengan Kejadian Stunting, sebaliknya terdapat Hubungan yang signifikan antara Tinggi Badan Ayah p-value $<\alpha 0,05(0,004>0,05)$ dengan Kejadian Stunting. Hubungan yang terdapat pada variabel ini merupakan hubungan yang searah artinya semakin baik pola pemberian makan maka tingkat kejadian stunting akan berkurang dengan meningkatkan pola pemberian makan.
\end{abstract}

Kata Kunci: Anak Balita, Kejadian Stunting, Pola Makan, Tinggi Badan Orang tua

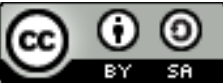

This is an open-acces article distributed under the terms of the Creative Commons Attribution-ShareAlike 4.0 International License.

\section{PENDAHULUAN}

Stunting merupakan indikator kekurangan gizi kronis akibat ketidakcukupan asupan makanan dalam waktu yang lama, pemberian makan yang kurang tepat, kualitas pangan yang buruk, meningkatnya morbiditas serta terjadinya peningkatan tinggi badan yang tidak sesuai dengan umurnya $(\mathrm{TB} / \mathrm{U})$. Pada umumnya, masalah pertumbuhan linier pada balita sering 
diabaikan karena masih dianggap normal asalkan berat badan anak telah memenuhi standar. Menurut beberapa penelitian, stunting berkaitan dengan peningkatan risiko kesakitan dan kematian serta terhambatnya pertumbuhan kemampuan motorik dan mental (Priyono, Sulistiyani dan Ratnawati, 2015).

Anak dikatakan stunting jika memiliki panjang atau tinggi badan dibawah standar untuk usianya. Diperkirakan dari 171 juta anak stunting di seluruh dunia, 167 juta anak (98\%) hidup dinegara berkembang. United Nations international Childeren's Emergency Fundation (UNICEF) mengatakan bahwa pada tahun 2011, 1 dari 4 anak balita mengalami stunting (Kemenkes, 2018).

Pembangunan kesehatan dalam periode tahun 2015-2019 difokuskan pada empat program prioritas yaitu penurunan angka kematian ibu dan bayi, penurunan prevalensi balita (stunting), pengendalian penyakit menular dan pengendalian penyakit tidak menular. Salah satu prioritas pembangunan nasional yang tercantum di dalam sasaran pokok Rencana Pembangunan jangka Menengah Tahun 2015-2019 yaitu upaya peningkatan status gizi masyarakat termasuk penurunan prevalensi balita stunting (Kemenkes, 2016).

Hal ini sejalan dengan penelitian yang dilakukan oleh Ariati et al (2018) dalam penelitian berjudul "Description of Nutritional Status and the Incidence of Stunting Children in early Childhood Education Programs in Bali-Indonesia" bahwa orang tua adalah pemberi dan harus memperhatikan kebutuhan pemenuhan gizi anak sehingga anak-anak tidak mengalami kekurangan gizi. Dan perlu dilakukan survey rutin untuk menentukan status gizi dan mencari faktor penyebab terjadinya gizi buruk dan stunting.

World Health Organization (WHO) (2018), mengatakan bahwa retardasi pertumbuhan atau stunting pada anak-anak di negara berkembang terjadi terutama sebagai akibat dari kekurangan gizi kronis dan penyakit infeksi yang mempengaruhi 30\% dari anak-anak usia di bawah lima tahun WHO (2018), mengatakan bahwa anak yang lahir dari ibu dengan tinggi badan kurang dari $150 \mathrm{~cm}$ lebih berisiko pada kejadian stunting. Tinggi badan ibu dan ayah yang pendek merupakan faktor risiko stunting (WHO, 2018).

World Health Organisation (WHO), telah menargetkan akan menurunkan angka stunting sebesar $40 \%$ pada tahun 2025 atau sekitar 70 juta anak yang diselamatkan dari stunting. Tahun 2017 22,2\% atau sekitar 150,8 juta balita di dunia mengalami stunting. Lebih dari setengah balita stunting di dunia berasal dari Asia (55\%), sedangkan lebih dari sepertiganya (39\%) tinggal di Afrika. Dari 83,6 juta balita stunting di Asia, proporsi terbanyak berasal dari Asia Selatan $(58,7 \%)$ dan proporsi paling sedikit di Asia Tengah $(0,9 \%)$ (Kemenkes RI, 2018).

Dampak stunting tidak hanya dirasakan oleh individu yang mengalaminya, tetapi juga berdampak terhadap roda perekonomian dan pembangunan bangsa. Hal ini karena sumberdaya manusia stunting memiliki kualiatas lebih rendah dibandingkan dengan sumber daya manusia normal (Bentian, 2017).

Menurut UNICEF, stunting berdampak pada tingkat kecerdasan, kerentanan terhadap penyakit, menurunnya produktifitas dan kemudian menghambat pertumbuhan ekonomi, meningkatkan kemiskinan. Oleh karena itu, solusi dari masalah ini dimana stunting perlu mendapat perhatian khusus termasuk pada anak usia 12-36 bulan. Proses pertumbuhan pada usia 12-59 bulan cenderung mengalami perlambatan sehingga peluang untuk terjadinya stunting.

Usia 12-59 bulan merupakan usia anak mengalami perkembangan yang pesat dalam kemampuan kognitif dan motorik. Diperlukan kondisi fisik yang maksimal untuk mendukung perkembangan ini, dimana pada anak yang 12-59 bulan perkembangan kemampuan motorik maupun kognitif dapat terganggu. Anak pada usia ini juga membutuhkan perhatian lebih dalam hal asupan karena kebutuhan energi yang lebih tinggi dan kebutuhan makanan yang lebih bervariasi. 
Berdasarkan fenomena di atas maka penelitian ini dilakukan untuk mengetahui apakah pola makan dan tinggi badan orang tua berhubungan dengan terjadinya Stunting pada anak usia 12-36 bulan di Puskesmas Kinovaro Kabupaten Sigi Provinsi Sulawesi Tengah.

Tujuan Penelitian yang akan saya lakukan meliputi Tujuan Umum dan Tujuan Khusus. Yang pertama Tujuan Umum dimana Tujuan ini Menganalisis Kejadian Stunting ditinjau dari Pola Makan dan Tinggi Badan Orang Tua Anak Usia 12-36 Bulan di Puskesmas Kinovaro Kabupaten Sigi Provinsi Sulawesi Tengah. Kedua Tujuan Khusus terdiri dari, Mengidentifikasi Kejadian Stunting Pada Anak Usia 12-36 Bulan Di Puskesmas Kinovaro Kabupaten Sigi Provinsi Sulawesi Tengah, Mengidentifikasi Pola Makan Pada Anak Usia 12-36 Bulan Di Puskesmas Kinovaro Kabupaten Sigi Provinsi Sulawesi Tengah, Mengidentifikasi Tinggi Badan Orang Tua Pada Anak Usia 12-36 Bulan Di Puskesmas Kinovaro Kabupaten Sigi Provinsi Sulawesi Tengah, Menganalisis Hubungan Pola Makan dengan Kejadian Stunting Pada Anak Usia 12-36 Bulan Di Puskesmas Kinovaro Kabupaten Sigi Provinsi Sulawesi Tengah, Menganalisis Hubungan Tinggi Badan Orang Tua dengan Kejadian Stunting Pada Anak Usia 12-36 Bulan Di Puskesmas Kinovaro Kabupaten Sigi Provinsi Sulawesi Tengah.

\section{METODE}

Desain penelitian yang digunakan dalam penelitian ini adalah penelitian korelasional, dengan pendekatan Cross-secrional. Populasi dalam penelitian ini adalah semua orang tua dan anak usia 12-36 bulan, sampel yang digunakan adalah Sebagian orang tua dan anak usia 12-36 bulan di Wilayah Kerja Puskesmas Kinovaro Kabupaten Sigi Provinsi Sulawesi Tengah, dengan jumlah sampel sebanyak 85 responden. Dalam penelitian ini, peneliti mengambil sampel dengan menggunakan teknik Simple Random Sampling. Pada definisi operasional variabel pola makan alat ukurnya menggunakan kuesioner dengan kategori Tidak Tepat $(<55 \%)$ dan Tepat (55\%-100\%), pada variabel tinggi badan orang tua alat ukurnya menggunakan microtoise dengan ketepatan $1 \mathrm{~cm}$ dengan kategori pendek dan tinggi, sedangkan untuk variabel kejadian stunting alat ukurnya menggunakan observasi dengan table Z-Score antropometri indeks TB/U dengan kategori Sangat pendek (<-3SD) dan Pendek (-3SD sampai <-2SD). Analisis data untuk melihat hubungan antara variabel independent dengan variabel dependen dengan menggunakan uji statistik Phi dengan nilai signifikasi $\alpha=0,05$.

\section{HASIL}

\section{A. Data khusus}

1. Kejadian Stunting

Tabel 2.1 Variabel Kejadian Stunting pada anak usia 12-36 bulan di Puskesmas Kinovaro Kabupaten Sigi Provinsi Sulawesi Tengah pada bulan Februari 2020.

\begin{tabular}{lllc}
\hline Variabel & Kategori & F & \% \\
\hline Kejadian & Sangat Pendek & 47 & $56 \%$ \\
Stunting & Pendek & 38 & $44 \%$ \\
\hline Total & & $\mathbf{8 5}$ & $\mathbf{1 0 0} \%$
\end{tabular}

Berdasarkan tabel di atas didapatkan bahwa sebagian besar responden memiliki kejadian Stunting dengan kategori Sangat Pendek yaitu sebanyak 47 responden dengan presentase (56\%)

2. Pola Pemberian Makan

Tabel 2.2 Variabel Pola Pemberian Makan pada anak usia 12-36 bulan

\begin{tabular}{lllc}
\hline Variabel & Kategori & F & \% \\
\hline Pola Pemberian & Tidak Tepat & 63 & $74 \%$ \\
Makan & Tepat & 22 & $26 \%$ \\
\hline Total & & $\mathbf{8 5}$ & $\mathbf{1 0 0 \%}$ \\
\hline
\end{tabular}


Berdasarkan tabel di atas didapatkan bahwa sebagian besar responden memiliki pola pemberian makan dengan kategori Tidak Tepat yaitu sebanyak 63 responden dengan presentase $(74 \%)$.

3. Tinggi Badan Orang tua (Ayah)

Tabel 2.3 Variabel tinggi badan Orangtua (Ayah) di Puskesmas Kinovaro Kabupaten Sigi Provinsi Sulawesi Tengah pada Bulan Februari 2020

\begin{tabular}{llll}
\hline Variabel & Kategori & F & \% \\
\hline Tinggi Badan & $<161,9 \mathrm{~cm}$ & 27 & $32 \%$ \\
Ayah & $\geq 161,9 \mathrm{~cm}$ & 58 & $68 \%$ \\
\hline Total & & $\mathbf{8 5}$ & $\mathbf{1 0 0} \%$
\end{tabular}

Berdasarkan tabel di atas didapatkan bahwa sebagian besar responden memiliki tinggi badan $\geq 161,9 \mathrm{~cm}$ yaitu sebanyak 58 responden dengan presentase $(68 \%)$.

4. Tinggi Badan Orang Tua (Ibu)

Tabel 2.4 Variabel tinggi badan Orangtua (Ayah) di Puskesmas Kinovaro Kabupaten Sigi Provinsi Sulawesi Tengah pada Bulan Februari 2020

\begin{tabular}{llll}
\hline Variabel & Kategori & F & $\%$ \\
\hline Tinggi Badan & $<150 \mathrm{~cm}$ & 55 & $64 \%$ \\
Ibu & $\geq 150 \mathrm{~cm}$ & 30 & $36 \%$ \\
\hline Total & & 85 & $100 \%$
\end{tabular}

Berdasarkan tabel di s atas didapatkan bahwa sebagian besar responden memiliki tinggi badan $<150 \mathrm{~cm}$ yaitu sebanyak 55 responden dengan presentase $(64 \%)$

\section{B. Tabulasi Silang antar Variabel}

1. Variabel hubungan Pola Pemberian Makan dengan Kejadian Stunting

Tabel 3.1 Tabulasi Silang antar variabel pola pemberian makan dengan kejadian Stunting pada anak usia 12-36 bulan di Puskesmas Kinovaro Kabupaten Sigi Provinsi Sulawesi Tengah pada Bulan Februari 2020

\begin{tabular}{|c|c|c|c|c|c|c|}
\hline \multirow{3}{*}{$\begin{array}{c}\text { Pola Pemberian } \\
\text { Makan }\end{array}$} & \multicolumn{4}{|c|}{ Stunting } & \multirow{2}{*}{\multicolumn{2}{|c|}{ Total }} \\
\hline & \multicolumn{2}{|c|}{ Pendek } & \multicolumn{2}{|c|}{ Sangat Pendek } & & \\
\hline & $\mathbf{F}$ & $\%$ & $\mathbf{F}$ & $\%$ & $\mathbf{F}$ & $\%$ \\
\hline Tidak Tepat & 25 & $29 \%$ & 38 & $45 \%$ & 63 & $74 \%$ \\
\hline Tepat & 13 & $15 \%$ & 9 & $11 \%$ & 22 & $26 \%$ \\
\hline Total & 38 & $44 \%$ & 47 & $56 \%$ & 85 & $100 \%$ \\
\hline
\end{tabular}

Berdasarkan tabel di atas sebagian besar pola pemberian makan dengan kategori tidak tepat dengan kategori kejadian stunting dalam kategori Sangat pendek yaitu sebesar 38 (45\%). Hasil uji statistik menggunakan uji phi diperoleh nilai Approx.Sig sebesar $p=0,002 \leq 0,05$ yang artinya ada hubungan antara pola pemberian makan dengan kejadian stunting.

2. Variabel hubungan Tinggi Badan Orang Tua (Ayah) dengan Kejadian Stunting

Tabel 3.2 Tabulasi Silang antar variabel Tinggi Badan Orang Tua (Ayah) dengan Kejadian Stunting pada anak usia 12-36 bulan di Puskesmas Kinovaro Kabupaten Sigi Provinsi Sulawesi Tengah pada Bulan Februari 2020 


\begin{tabular}{|c|c|c|c|c|c|c|}
\hline \multirow{3}{*}{ Tinggi } & \multicolumn{4}{|c|}{ Stunting } & \multirow{2}{*}{\multicolumn{2}{|c|}{ Total }} \\
\hline & \multicolumn{2}{|c|}{ Pendek } & \multicolumn{2}{|c|}{ Sangat Pendek } & & \\
\hline & $\mathbf{F}$ & $\%$ & $\mathbf{F}$ & $\%$ & $\mathbf{F}$ & $\%$ \\
\hline$<161,9 \mathrm{~cm}$ & 6 & $7 \%$ & 21 & $25 \%$ & 27 & $32 \%$ \\
\hline$\geq 161,9 \mathrm{~cm}$ & 32 & $37 \%$ & 26 & $31 \%$ & 58 & $68 \%$ \\
\hline Total & 38 & $44 \%$ & 47 & $56 \%$ & 85 & $100 \%$ \\
\hline
\end{tabular}

Uji Phi Nilai Value Phi 0,309; Approx. Sig 0,004

Berdasarkan tabel di atas sebagian besar tinggi badan orang tua (Ayah) dengan kejadian stunting dalam kategori pendek 32 (37\%). Hasil uji statistik menggunakan uji phi diperoleh nilai Approx.Sig sebesar $p=0,004 \leq 0,05$ yang artinya ada hubungan antara tinggi badan ayah dengan kejadian stunting.

3. Variabel hubungan Tinggi Badan Orang Tua (Ibu) dengan Kejadian Stunting.

Tabel 3.3 Tabulasi Silang antar variabel Tinggi Badan Orang Tua (Ibu) dengan Kejadian Stunting pada anak usia 12-36 bulan di Puskesmas Kinovaro Kabupaten Sigi Provinsi Sulawesi Tengah pada Bulan Februari 2020

\begin{tabular}{lllllll}
\hline \multirow{2}{*}{\begin{tabular}{c} 
Pola Pemberian $\begin{array}{c}\text { Stunting } \\
\text { Makan }\end{array}$ \\
\cline { 2 - 6 }
\end{tabular}} & \multicolumn{7}{c}{ Pendek } & \multicolumn{2}{c}{ Sangat Pendek } & \\
\cline { 2 - 6 } & F & $\mathbf{\%}$ & F & \% & F & \% \\
\hline$<151 \mathrm{~cm}$ & 10 & $12 \%$ & 20 & $24 \%$ & 30 & $36 \%$ \\
\hline$\geq 151 \mathrm{~cm}$ & 28 & $32 \%$ & 27 & $32 \%$ & 55 & $64 \%$ \\
\hline Total & $\mathbf{3 8}$ & $\mathbf{4 4 \%}$ & $\mathbf{4 7}$ & $\mathbf{5 6 \%}$ & $\mathbf{8 5}$ & $\mathbf{1 0 0 \%}$ \\
\hline
\end{tabular}

Uji Phi Nilai Value Phi 0,167; Approx. Sig 0,119

Berdasarkan tabel di atas sebagian besar tinggi badan orang tua (Ayah) dengan kejadian stunting dalam kategori pendek 28 (32\%). Hasil uji statistik menggunakan uji phi diperoleh nilai Approx.Sig sebesar $p=0,119 \leq 0,05$ yang artinya tidak ada hubungan antara tinggi badan ayah dengan kejadian stunting

\section{PEMBAHASAN}

Pola Pemberian Makan anak usia 12-36 bulan di Puskesmas Kinovaro

Pada hasil penelitian ini di wilayah kerja Puskesmas Kinovaro yang didapatkan bahwa pola pemberian makan dengan 85 responden sebagian besar dlam kategori pola pemberian makan tidak tepat yaitu sebanyak 63 responden $(74 \%)$.

Hasil penelitian yang dilakukan (Ridha, 2018) menjukkan bahwa pola pemberian yang tepat merupakan pola pemberian makan yang sesuai dengan jenis makanan, jumlah makanan dan jadwal makan anak.

Pola pemberian makan merupakan faktor determinan terjadinya stunting teritama pada anak di bawah usia 5 tahun, dimana oleh sebagian besar masyarakat pola pemberian makannya kurang tepat begitu pula pada masyarakat di wilayah Puskesmas Kinovaro, padahal pada masa ini kebutuhan zat gizi anak akan terpenuhi apabila makanan yang dia konsumsi memenuhi standar pemberian makanan sesuai yang di tetapkan oleh WHO. Jenis konsumsi makanan juga sangat menentukan status gizi anak. Hal ini disebabkan karena balita merupakan kelompok rawan gizi sehingga jenis makanan yang diberikan harus sesuai dengan kebutuhan tubuh anak dan daya cerna. Jenis makanan yang lebih variatif dan cukup nilai gizinya sangat penting untuk menghindari anak kekurangan zat gizi. Pola pemberian makan yang baik harus dilakukan sejak dini dengan cara memberikan makanan yang bervariasi dan memberikan informasi kepada anak. Dengan demikian, anak akan terbiasa dengan pola makan sehat. Stunting tidak hanya 
berdampak pada individu yang mengalaminya, tetapi berdampak pada roda perekonomian dan pembangunan bangsa. Oleh karena itu, semakin banyak ibu memberikan pola makan yang tepat pada anak balita terkhususnya pada masa 1000 hari pertama kehidupan maka semakin sedikit anak balita yang mengalami stunting.

\section{Tinggi Badan Orang Tua pada Anak Usia 12-36 Bulan di Puskesmas Kinovaro}

Pada hasil penelitian ini Responden di wilayah kerja Puskesmas Kinovaro yang terdapat pada table distribusi frekuensi Tinggi Badan Orang Tua (Ayah) dengan menggunakan pengukuran microtois, dimana dari 85 responden didapatkan hasil sebagian besar memiliki tinggi badan yang tidak pendek dengan nilai ambang $\geq 161,9 \mathrm{~cm}$ yaitu sebanyak 58 responden (68\%). Sedangkan distribusi frekuensi tinggi badan orang tua (Ibu) dengan menggunakan pengukuran microtois, dimana dari 85 responden didapatkan hasil sebagian besar memiliki tinggi badan yang tidak pendek dengan nilai ambang $\geq 150 \mathrm{~cm}$ yaitu sebanyak 55 responden $(64 \%)$.

Terdapat pendapat mengatakan bahwa anak yang lahir dari ibu dengan tinggi badan kurang dari $150 \mathrm{~cm}$ dan untuk kategori ayah tinggi badan kurang dari 161,9 cm lebih berisiko pada kejadian stunting. Tinggi badan ibu dan ayah yang pendek merupakan factor risiko stunting. WHO juga menargetkan akan menurunkan angka stunting sebesar $40 \%$ pada tahun 2025 atau sekitar 70 juta anak yang diselamatkan dari stunting.

Ibu pendek yang memiliki tinggi badan $<150 \mathrm{~cm}$ mempunyai peluang lebih besar melahirkan bayi yang pendek Stunting sebesar 2,04 kali dari pada ibu dengan tinggi badan > $150 \mathrm{~cm}$. Hal ini karena aliran darah Rahim dan pertumbuhan uterus, plasenta dan janin pada ibu hamil pendek terbatas sehingga bayi yang dilahirkan memiliki retardasi pertumbuhan janin yang dikenal dengan IUGR (Intra Uterine Growth Retardation).

Dimana dalam penelitian ini Tidak semua ibu dan ayah pendek memiliki anak pendek (Stunting), meskipun terdapat kecendrungan pada ibu pendek akan melahirkan anak yang pendek atau orang tua (ayah maupun ibu) yang pendek akan mempunyai keturunan yang pendek pula. Namun apabila pola pemberian makan dilakukan dengan tepat, anak akan tumbuh sehat dan optimal.

Kejadian stunting pada anak usia 12-36 bulan di wilayah Puskesmas Kinovaro

Hasil pada penelitian ini menunjukkan bahwa dari 85 anak didapatkan sebagian besar anak memiliki kejadian stunting dengan kategori Sangat Pendek dengan perincian sebanyak 47 anak dengan presentase (56\%) memiliki kategori sangat pendek.

Hasil penelitian ini sejalan dengan penelitian yang dilakukan Bella Safira tahun 2019 menunjukkan dari 60 responden terdapat 20 balita $(33,3 \%)$ yang mengalami stunting, angka ini sangat tinggi dibanding temuan dalam penelitian ini. Stunting merupakan indikator kekurangan gizi kronis akibat ketidakcukupan asupan makanan dalam waktu yang lama, pemberian makan yang kurang tepat, kualitas pangan yang buruk, meningkatkan morbaditas serta terjadinya peningkatan tinggi badan yang tidak sesuai dengan umurnya.

Tingginya angka kejadian stunting pada tahun 2020 di wilayah Puskesmas Kinovaro Sulawesi Tengah disebabkan oleh kekurangan gizi yang menjadi pemicu utama terjadinya stunting, di mana suatu kondisi tinggi badan lebih pendek dibanding orang lain yang seusianya. Oleh karena itu kita sebagai tenaga Kesehatan mempunyai peran yang sangat penting dalam melakukan pelayanan untuk pencegahan serta mengurangi angka kejadian stunting di masa depan. 
Hubungan Pola Makan dengan Kejadian Stunting pada anak usia 12-36 Bulan

Berdasarkan Hasil uji statistik menggunakan uji phi diperoleh nilai Approx.Sig sebesar $\mathrm{p}=$ $0,002 \leq 0,05$ yang artinya ada hubungan antara pola pemberian makan dengan kejadian stunting.

Hasil penelitian ini sejalan dengan Eko Setiawan tahun 2018 bahwa terdapat hubungan yang sangat bermakna antara pola pemberian makan dengan Kejadian Stunting dimana terdapat perbedaan tingkat kecukupan asupan energi yang adejuat merupakan hal yang sangat penting bagi anak. Energi tersebut bersumber dari mikronutrien seperti: karbohidrat, lemak, dan protein.

Disini kita sebagai tenaga Kesehatan mempunyai peran yang sangat penting dalam melakukan pelayanan agar selalu memberikan Asuhan dan Masukan kepada ibu terkhususnya yang mempunyai anak usia 12-36 bulan dalam pemberian makanan dan minuman yang diberikan sehari hari dengan melihat kandungan gizi yang terkandung dalam makanan tersebut. Tidak semua makanan murah tidak mempunyai nilai gizi yang tinggi serta sebaliknya tidak semua makanan mahal mempunyai nilai gizi yang tinggi juga. Jadilah orang tua yang bijak dalam memilih asupan gizi yang baik untuk anak. Cegah Stunting dari sekarang jika bukan kita siapa lagi, jika bukan sekarang kapan lagi.

Hubungan Tinggi Badan Orang Tua dengan Kejadian Stunting anak usia 12-36 Bulan di wilayah Puskesmas Kinovaro

Pada hasil penelitian ini terdapat hubungan antara Tinggi badan orang tua Ayah dengan kejadian stunting pada anak usia 12-36 bulan. Dari hasil uji statistik yang diperoleh menggunakan uji phi dimana nilai Approx Sig. 0,004 lebih kecil dari 0,05 sehingga diputuskan terdapat hubungan antara tinggi badan orang tua (Ayah) dengan kejadian stunting, jika dilihat dari nilai kefisiensi phi 0,309 .

Sedangkan hasil penelitian tinggi badan orang tua Ibu didapatkan tidak terdapat hubungan antara tinggi badan dengan kejadian stunting, dengan hasil uji statistik yang diperoleh menggunakan uji phi dimana nilai Approx Sig. 0,119 lebih besar dari 0,05 sehingga diputuskan tidak ada hubungan antara tinggi badan orang tua (Ibu) dengan kejadian stunting, jika dilihat dari nilai kefisiensi phi 0,167 .

Seperti penelitian yang dilakukan Nur Hadibah (2019) bahwa hasil analisis berdasarkan uji Chi-Square menunjukkan tidak terdapat hubungan yang tidak bermakna antara tinggi badan ibu dengan kejadian stunting pada balita usia 24-59 bulan $(\mathrm{p}=0,704)$.

Ternyata Hasil penelitian ini menjukkan bahwa tinggi badan orang tua khususnya ayah terdapat keterkaitan atau hubungan yang sangat signifikan dengan kejadian stunting. Berbeda dengan halnya tinggi badan Ibu, dalam penelitian ini, tidak terdapat hubungan antara tinggi badan ibu dengan kejadian stunting anak.

Namun apabila orang tua pendek tersebut akibat karena factor masalah gizi yang dialami orang tua maka belum tentu memiliki anak pendek sehingga ibu dan ayah pendek tidak semua memiliki pengaruh terhadap tinggi badan anakknya.

\section{KESIMPULAN}

Dari total 85 responden anak dengan kejadian stunting di Puskesmas Kinovaro, sebagian besar dengan kategori sangat pendek yaitu sebanyak 47 anak (56\%). Pada Pola pemberian makan didapatkan Sebagian besar 63 responden (74\%) pada kategori tidak tepat. Pada tinggi badan ayah didapatkan Sebagian besar 58 responden $(68 \%)$ pada kategori $\geq 161,9 \mathrm{~cm}$, tinggi badan ibu didapatkan sebagian besar 55 responden $(64 \%)$ pada kategori $\geq 150 \mathrm{~cm}$ dari 85 responden. Pada Uji statistik Phi menunjukkan bahwa terdapat hubungan antara Pola pemberian makan p-value $<\alpha 0,05(0,002<0,05)$ dan Tinggi Badan Ibu p-value $>\alpha 0,05$ 
$(0,119>0,05)$ dengan Kejadian Stunting, terdapat Hubungan yang signifikan antara Tinggi Badan Ayah p-value $<\alpha 0,05(0,004>0,05)$ dengan Kejadian Stunting.

\section{REFERENSI}

Ariani, Ayu Putri. 2017. Ilmu Gizi. Yogyakarta: Nuha Medika.

Amin, N. A. \& Julia, M.2018. Faktor Sosio demografi dan Tinggi Badan Orang Tua serta Hubungannya dengan Kejadian Stunting pada Balita Usia 6-23 Bulan. J. Gizi dan Diet. Indones. 2, 170-177 (2014).

Anindita P. 2019. Hubungan tingkat pendidikan ibu, pendapatan keluarga, kecukupan protein \& zinc dengan stunting (pendek) pada balita usia 6-35 bulan di Kecamatan Tembalang Kota Semarang. J Kesehat Masyarakat. 2019;1(2):617-26.

Ariati, N. N., Fetria, A., Purnamawati, A. A. P., Suarni, N. N., Padmiari, I. A. E., \& Sugiani, P. P. S. (2018). Description of nutritional status and the incidence of stunting children in early childhood education programs in Bali-Indonesia. Bali Medical Journal, 7(3), 723726. https://doi.org/10.15562/bmj.v7i3.1219

Arra, Prasad Bhanu. 2019. Examining The Distribution Of Stunting Under-5 Years Old Children In Armenia. Master's Thesis, 53 pages, 3 Appendices. Journal-Internasional. http://epublications.uef.fi/pub/urn_nbn_fi_uef20190640/urn_nbn_fi_uef-20190640.pdf.

Diakses pada tanggal 5 Desember 2019, Pukul 22.00 WIB

Bentian I, Mayulu N, Rattu AJM. 2017. Faktor risiko terjadinya stunting pada anak TK di wilayah kerja Puskesmas Siloam Tamako Kabupaten Kepulauan Sangihe Provinsi Sulawesi Utara. Jurnal Ilmu Kesehatan Masyarakat Unsrat. 2017;5(1):1-7.

Budiastutik, I., \& Nugraheni, A. (2018). Determinants of Stunting in Indonesia: A Review Article. International Journal Of Healtcare Research, 1(1), 2620-5580.

Illahi RK. 2017. Hubungan pendapatan keluarga, berat lahir, dan panjang lahir dengan kejadian stunting balita 24-59 bulan di Bangkalan. J Manaj Kesehat Yayasan RS Dr Soetomo. 2017;3(1):1-14.

Kartikawati. 2019. Hubungan Tinggi Badan Ibu dengan Kejadian Stunting Pada Balita Usia 24-59 Bulan. Keperawatan dan Kebidanan Aisyiyah 10, 15-24 (2019).

[Kemenkes RI] Kementerian Kesehatan Republik Indonesia (2015) 'Infodatin - Situasi dan Analisis Gizi', Kemenkes RI, Pusat data dan informasi,pp.1-7.

Nur Hadibah Hanum. (2019). Hubungan Tinggi Badan Ibu dan Riwayat Pemberian MP-ASI dengan Kejadian Stunting pada Balita Usia 24-59 Bulan. Amerta Nutrition, 3(2), 78-84. https://doi.org/10.2473/amnt.v3i2.2019.78-84

Pacheco, C. D. R., Picauly, I., \& Sinaga, M. (2017). Health, Food Consumption, Social Economy, and Stunting Incidency in Timor Leste. Jurnal Kesehatan Masyarakat, 13(2), 261-269. https://doi.org/10.15294/kemas.v13i2.11248

Prakhasita, R. C. (2018). Hubungan Pola Pemberian Makan Dengan Kejadian Stunting Pada Balita Di Wilayah Kerja Puskesmas Tambak Wedi Surabaya. Hubungan Pola Pemberian Makan Dengan Kejadian Stunting Pada Balita Di Wilayah Kerja Puskesmas Tambak Wedi Surabaya.

Rita, S., \& Sulistianingsih, A. (2017). Faktor Determinan Yang Berhubungan Dengan Kejadian Stunting Pada Balita Di Kabupaten Pesawaran Lampung. Jurnal Wacana Kesehatan, 2(2), 208-218.

Retrieved

from

http://jurnal.akperdharmawacana.ac.id/index.php/wacana/article/view/51/26

Setiawan, E., Machmud, R., \& Masrul, M. (2018). Faktor-Faktor yang Berhubungan dengan Kejadian Stunting pada Anak Usia 24-59 Bulan di Wilayah Kerja Puskesmas Andalas Kecamatan Padang Timur Kota Padang Tahun 2018. Jurnal Kesehatan Andalas, 7(2), 275. https://doi.org/10.25077/jka.v7i2.813 
Sulastri D. 2017. Faktor determinan kejadian stunting pada anak usia sekolah di Kecamatan Lubuk Kilangan Kota Padang. Padang: Majalah Kedokteran Andalas. 2017;1(36):39-50.

Sulistyawati, Ari. 2017. Asuhan Kebidanan Pada Masa Kehamilan. Salemba Medika. Jakarta.

Vaozia S, Nuryanto. 2017. Faktor risiko kejadian stunting pada anak usia 1-3 tahun (studi di Desa Menduran Kecamatan Brati Kabupaten Grobogan). Journal of Nutrition College. 2016;5(4):314-20.

World Health Organization. 2018. InterpretationGuide Nutrition Landscape Information System(NLIS). Switzerland: WHO Press.

World Health Organization. 2019. Target Penururan Angka Kejadian Stunting Tahun 2025. Switzerland: WHO Press. Diakses pada tanggal 2 Desember 2019, Pukul 12.00 WIB. 